\title{
Mitochondrial DNA depletion syndrome, myopathic form
}

INSERM

\section{Source}

INSERM. (1999). Orphanet: an online rare disease and orphan drug data base.

Mitochondrial DNA depletion syndrome, myopathic form. ORPHA:254875

Myopathic mitochondrial DNA ( $m$ tDNA) depletion syndrome is one of the main forms of mtDNA depletion syndrome (see this term) that displays a broad phenotypic spectrum but that is most often characterized by hypotonia, proximal muscle weakness, facial and bulbar weakness and failure to thrive. 